\title{
Habitat Structural Effect on Squamata Fauna of the Restinga Ecosystem in Northeastern Brazil
}

\author{
EDUARDO J.R. DIAS ${ }^{1}$ and CARLOS F.D. ROCHA ${ }^{2}$ \\ ${ }^{1}$ Laboratório de Biologia e Ecologia de Vertebrados (LABEV), Departamento de Biociências, Universidade Federal de Sergipe, \\ Campus Alberto de Carvalho, Av. Vereador Olímpio Grande, s/n, Centro, 49500-000 Itabaiana, SE, Brasil \\ ${ }^{2}$ Departamento de Ecologia, Instituto de Biologia Roberto Alcântara Gomes, Universidade do Estado do Rio de Janeiro, \\ Rua São Francisco Xavier, 524, Maracanã, 20550-019 Rio de Janeiro, RJ, Brasil
}

Manuscript received on January 14, 2013; accepted for publication on July 5, 2013

\begin{abstract}
In this work, we surveyed data on richness and composition of squamatan reptiles and habitat structural effect in nine areas of restinga ecosystem in the State of Bahia, northeastern Brazil. The "restinga" ecosystems are coastal sand dune habitats on the coast of Brazil. Our main hypothesis is that the Squamata fauna composition along these restinga areas would be modulated by habitat structural. After 90 days of field sampling we recorded approximately 5\% of reptile species known in Brazil. The composition of Squamata assemblages varied mainly based on the presence or absence of lizards of the genera Ameivula and Tropidurus. Our data showed that habitat structure consistently affected the composition of local Squamata fauna, especially lizards.
\end{abstract}

Key words: gradient analyses, habitat structure, lizards and snakes, restinga ecosystem, Northeastern Brazil.

\section{INTRODUCTION}

The organization of assemblages in terms of species diversity, their abundances and niche relationships among component species is an interesting issue of ecology. Studies on lizard assemblages suggest that sympatric species may segregate primarily for food, activity period and habitat, but the causes of segregation are still unknown (e.g. Pianka 1973, 1986, Schoener 1974, Losos 1994). However, different trends are related with the maintenance of the interactions among sympatric species in the assemblages (Schoener 1968, Pianka 1973, Vitt 1995, Vitt and Carvalho 1995). The nature of these ecological trends varies taxonomically and

Correspondence to: Eduardo José dos Reis Dias

E-mail: ejrdias@hotmail.com between locations, indicating that other factors (e.g. phylogeny, biogeography) have important role in determining the composition of the present species in the different assemblages (Losos 1994, Vitt 1995, Vitt et al. 1999).

Many studies have shown that biogeographic factors may be responsible for differences between assemblages and most analyses have provided general explanations based on historical factors (e.g. Haffer 1969, Vanzolini 1988, Losos 1994).

In this context of evolution, phylogeny and biogeography, knowing why some assemblages tend to harbors more species than others is one of the interesting questions in community ecology. In terms of evolution, the patterns of speciation or extinction generally define the set of species available in 
determined areas as a result of environmental differences between regions (Losos 1994).

The "restinga" ecosystem (coastal sand dune habitats), in the coast of Brazil, can be subdivided into different zones, characterized by the local topography and floristic physiognomy (Dansereau 1947, Ormond 1960, Araujo et al. 1998, CogliattiCarvalho et al. 2001, 2010). The variation in the composition and structure of vegetation in the restinga along the Brazilian coast is affected by environmental variables such as salinity, salt spray, sand movement, humidity and soil quality (nutrients), as well as variation of groundwater level (Ormond 1960, Franco et al. 1984, Henriques et al. 1986, Pereira et al. 1992). In this context, usually there is an environmental gradient which increases the spatial heterogeneity in the restinga from the beach habitats of restinga (just seaside) towards the more shaded environments with vegetation (Lacerda et al.1993, Cogliatti-Carvalho et al. 2001).

The species of plants along restinga differ in terms of abundance, richness and dominance, and these differences can be translated in habitat types in this environment (Scarano 2002, Araujo et al. 2004, Cogliatti-Carvalho et al. 2010). Thus, the distribution of these habitat types in nature in the restinga plays an important role in the success of the local animals species and may directly affect structural aspects of their assemblages such as richness, abundance and composition of the communities (Rocha and Bergallo 1997).

Herein we analyze parameters of the Squamata fauna including species richness and composition, occurrences and distribution based on standardized surveys in nine restinga ecosystems in the State of Bahia along approximately 1,200 km of Brazilian coast in northeastern Brazil. Our main hypothesis is that the Squamata fauna composition along these restinga areas on the coast of the State of Bahia would be modulated by habitat structured on the local ecosystems.

\section{MATERIALS AND METHODS}

We surveyed data of richness and composition of squamatan reptiles, including features of habitat structure in nine areas of the restinga ecosystem along approximately $1,200 \mathrm{~km}$ on the coast of the State of Bahia, several of them located within the Central Biodiversity Corridor of the Atlantic Forest domains in Brazil. We studied the following areas: Costa Azul $\left(11^{\circ} 40^{\prime} 28^{\prime \prime} \mathrm{S}\right.$ and $\left.37^{\circ} 29^{\prime} 03^{\prime \prime} \mathrm{W}\right)$ in the municipality

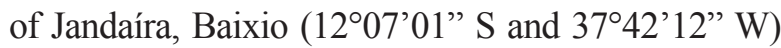
in Esplanada, Guarajuba (12 $38^{\prime} 03^{\prime \prime} \mathrm{S}$ and $38^{\circ} 04^{\prime} 32^{\prime \prime}$ W) in Camaçari, Abaeté (12 $55^{\prime} 42^{\prime \prime} \mathrm{S}$ and $38^{\circ} 20^{\prime} 09^{\prime \prime}$ W) in Salvador, Guaibim (13 $17^{\circ} 43^{\prime \prime} \mathrm{S}$ and $38^{\circ} 57^{\prime} 59^{\prime \prime}$ W) in Valença, Boipeba (13 $36^{\circ} \mathrm{S}$ and $38^{\circ} 54^{\prime} \mathrm{W}$ ) in Cairú, Cassange (13 ${ }^{\circ} 58^{\prime} \mathrm{S}$ and $\left.38^{\circ} 56^{\prime} \mathrm{W}\right)$ in Maraú, Taipe $\left(16^{\circ} 31^{\prime} \mathrm{S}\right.$ and $\left.39^{\circ} 05^{\prime} \mathrm{W}\right)$ in Porto Seguro and Nova Viçosa (1758'26'S and 39 28'29'W) (Fig. 1).

The data were obtained in each restinga during the dry seasons (September to February) in 2003, 2004 and 2005; the sampling periods involved 10 consecutive days in each of the nine areas studied during which we made an intensive survey of the local Squamata fauna. In each locality we surveyed the Squamata fauna establishing 20 systems of pitfall traps, each of them composed of five plastic buckets - one central of $60 \mathrm{~L}$ associated with four of $20 \mathrm{~L}$ and arranged in an "X" way with a central bucket connected to each of the four peripheral buckets by a $5 \mathrm{~m}$ long fence. Each system of pitfall trap was placed at a distance of at least $150 \mathrm{~m}$ from each other, following the environmental gradient in the restinga, from coastline (seashore) towards inland, where there were more shaded environments. Additionally, 12 glue traps (with $0.08 \mathrm{~m}^{2}$ dimension each) were used in the surroundings of each pitfall trap system, which were established on the ground or on the base of bromeliads. Thus, each pit-fall system with the set of glue traps constituted one sampling unit. All traps were checked daily between 7:00 to 18:00. We also carried out an intensive active search constrained by time in different areas of the restinga. We systematically 


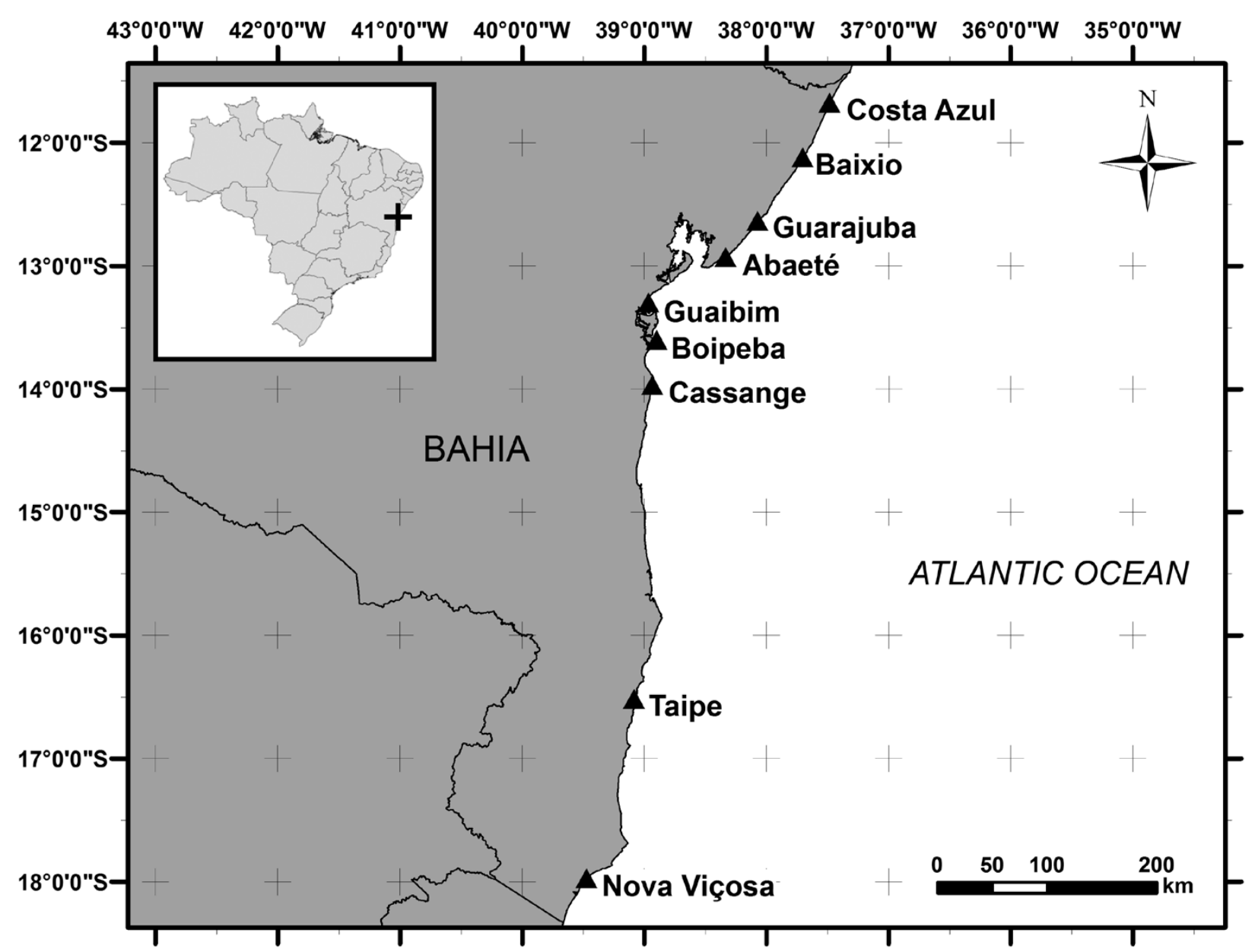

Fig. 1 - Sampled localities of nine restinga ecosystems along in the coast of the State of Bahia, northeastern Brazil.

moved at a slow walking pace in different transects (about $30 \mathrm{~min}$. each) from coastline towards inland along which we searched for Squamata reptiles in the different environments of the restinga.

The captured lizards were marked by toe clipping and released at the capture site to avoid registering a same individual twice and thus preserving the independence of data. The snakes and amphisbaenians (as well as 20 lizards of each species) were euthanized with ether, fixed with $10 \%$ formalin, preserved in alcohol as voucher specimens and deposited in the Museu de Zoologia da Universidade Federal da Bahia (MZUFBA). Recaptured lizards were not included in the analyses. All Squamata were collected under the IBAMA-RAN permit 056/02, 001/04 and 161/04).
We estimated some parameters of the habitat structure as an index of environmental heterogeneity along sampling units to evaluate the effect of features of the local environment of the restinga on the corresponding Squamata fauna surveyed. We established plots $(3 \times 3 \mathrm{~m})$ with a $50 \mathrm{~m}$ distance from each other, between each system of pitfall traps. In each plot we measured the occurrence or not of bromeliads and palm trees and registered their abundances, the vegetation height $(\mathrm{m})$ and frequency of clearings (represented by the space of uncovered ground in meters between bushes).

The species richness of Squamata was estimated by the Jackknife index for the construction of rarefaction curve (Krebs 1989) considering 
data from pooled sampling methods. To evaluate the effect of environmental heterogeneity between the areas we used the analysis of variance (ANOVA) and Bonferroni test (Zar 1999), as further examination of significance for differences between pairs of restingas. The relationship between richness and abundance of Squamata species and variables of environmental heterogeneity measured was performed using multiple regression analysis (Zar 1999).

We calculated the rate of species co-occurrence (C-score) (Stone and Roberts 1990), and the significance was tested by comparing them with null communities using the software ECOSIM (Gotelli and Entsminger 2001).
The multidimensional scaling (MDS) was applied to evaluate the similarity between restinga areas in terms of composition of Squamata species and of environmental heterogeneity and Biplot ordination analysis to describe which variables interfered in the data ordination (Kenkel and Orlóci 1986, Minchin 1997).

\section{RESULTS}

After 90 days of field sampling, corresponding to 1800 systems of pitfall traps sampling plus 495h/man of visual search, we captured 1101 individuals of 36 squamatan species: $20(55.5 \%)$ were lizards, 14 (39\%) snakes and two (5.5\%) amphisbaenians (Table I).

TABLE I

Composition and abundance of 36 Squamata species from nine restinga ecosystems studied along the coast of the State of Bahia, northeast Brazil. Study areas abbreviations: CA= Costa Azul; BX= Baixio; GJ= Guarajuba; ABT=Abaeté; $\mathbf{G B}=$ Guaibim; $\mathrm{BP}=$ Boipeba; $C S=$ Cassange; $\mathrm{TA}=$ Taipe $\mathbf{N V}=$ Nova Viçosa.

\begin{tabular}{|c|c|c|c|c|c|c|c|c|c|}
\hline \multirow{2}{*}{ Squamata species } & \multicolumn{9}{|c|}{ Study Areas } \\
\hline & $\mathbf{C A}$ & BX & GJ & ABT & GB & BP & CS & TA & NV \\
\hline \multicolumn{10}{|l|}{ Lizards } \\
\hline Ameivula abaetensis & 26 & 15 & 08 & 23 & & & & & \\
\hline Ameivula nativo & & & & & & 05 & 02 & 18 & 03 \\
\hline Ameivula ocellifera & 18 & 12 & 08 & 07 & & & & & \\
\hline Kentropyx calcarata & & & & & 03 & 02 & 06 & 02 & 04 \\
\hline Ameiva ameiva & & & 01 & & 01 & 02 & 06 & 05 & 04 \\
\hline Salvator merianae & 01 & & & & & 01 & & & \\
\hline Tropidurus hygomi & 77 & 171 & 158 & 141 & & & & & \\
\hline Tropidurus torquatus & & & & & 21 & 11 & 98 & 67 & 26 \\
\hline Polychrus marmoratus & & & & & 01 & & & & \\
\hline Iguana iguana & 01 & 01 & & & & & & & \\
\hline Psycosaura macrorhyncha & 08 & 07 & 06 & 02 & & 02 & 08 & & 01 \\
\hline Psycosaura agmosticha & 02 & & & & & & & & \\
\hline Brasiliscincus agilis & & & & & & & 02 & & \\
\hline Phyllopezus lutzae & 01 & & 05 & 01 & & 01 & 01 & & \\
\hline Coleodactylus meridionalis & 01 & 06 & 03 & & & & 02 & & \\
\hline Gymnodactylus darwinii & & & & & & 07 & 09 & 06 & 08 \\
\hline Hemidactylus mabouia & 01 & & & 01 & & & & 01 & 06 \\
\hline Micrablepharus maximiliani & & 01 & & & & & & & 01 \\
\hline Ecpleopus gaudichaudi & & & & & & & & & 15 \\
\hline Leposoma annectans & & & & & & & & 02 & \\
\hline Dryadosaura nordestina & 01 & & & & & & & & \\
\hline \multicolumn{10}{|l|}{ Amphisbaenians } \\
\hline Amphisbaena alba & 01 & 01 & & & & & & & \\
\hline Amphisbaena pretrei & & & & 01 & & & & & \\
\hline
\end{tabular}


TABLE I (continuation)

\begin{tabular}{|c|c|c|c|c|c|c|c|c|c|}
\hline \multirow{2}{*}{ Squamata species } & \multicolumn{9}{|c|}{ Study Areas } \\
\hline & CA & $\mathbf{B X}$ & GJ & ABT & GB & BP & CS & TA & $\mathbf{N V}$ \\
\hline \multicolumn{10}{|l|}{ Snakes } \\
\hline Boa constrictor & & & & & & 02 & & & \\
\hline Phimophis guerini & 01 & & 01 & & & & & & \\
\hline Sibynomorphus neuwiedi & 01 & & & & & & & & \\
\hline Oxyrhophus trigeminus & & 01 & & & & & & & \\
\hline Chironius exoletus & & & & & 01 & & & & \\
\hline Chironius bicarinatus & 01 & & & 01 & 03 & & 01 & & \\
\hline Chironius flavolineatus & & & & & 01 & & & & \\
\hline Philodryas olfersii & & & & 01 & & 01 & & & 01 \\
\hline Philodryas nattereri & & & 01 & & & & & & \\
\hline Philodryas patagoniensis & & 02 & & & & & & & \\
\hline Spilotes pullatus & 01 & & & & & & & & \\
\hline Tantilla melanocephala & & & & & & & 01 & & 01 \\
\hline Leptophis ahethulla & & & & & 01 & & & & \\
\hline Thyphlops brongersmianus & & & & & & 02 & & & \\
\hline
\end{tabular}

Among the nine studied restinga areas, Costa Azul was the richest with 15 species of Squamata (10 lizards, 01 snake and 04 amphisbaenians). The lowest richness was found in Taipe with 07 species of reptiles (only lizards) (Table I). The rarefaction curve showed the species richness in the studied areas (Fig. 2).

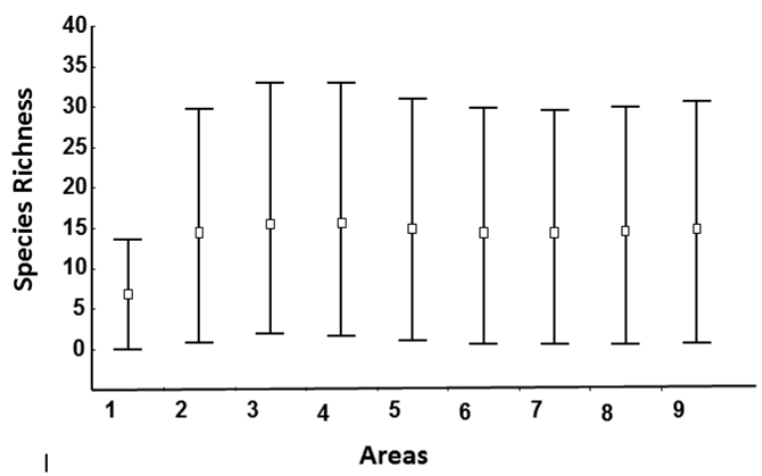

Fig. 2 - Rarefaction curve showing the species richness estimate by Jackknife index in nine restinga ecosystems studied on the coast of the State of Bahia, Brazil.

The analysis of co-occurrence (C-score) suggests that the distribution of species was not random in the Squamata assemblages studied (C-score obtained $=2.80 ;$ simulated $\mathrm{C}$-score $=2.63 ; P=0.001 ; 1000$ permutations), since the rate of co-occurrence of the species was significantly greater than expected.
The species composition of Squamata assemblages varied mainly as a result of the presence or absence of lizards of the genus Ameivula and Tropidurus. The MDS (stress $=0.284, R^{2}=0.998$ ) showed that three of the restinga areas located in the northern portion of the coast of the State of Bahia (Baixio, Guarajuba and Abaeté), were comparatively more similar in terms of lizard species composition. Similarly, the same analysis showed that three restinga areas located in the southern portion of the State of Bahia (Guaibim, Boipeba and Nova Viçosa), presented comparable similarity in terms of lizards species (Fig. 3). The Biplot analysis showed that the lizards Ameivula abaetensis, A.nativo, A.ocellifera, Tropidurus hygomi and T. torquatus were responsible for grouping the nine studied restinga areas into two distinct groups (Fig. 4 and 5).

The restinga of Costa Azul had the highest values of mean abundance of bromeliads and of palm trees $(9.7 \pm 10.7$ and $4.5 \pm 6.3$ respectively) whereas the restinga of Baixio had the highest mean frequency of clearings $(0.56 \pm 0.37)$ and the lowest mean value for vegetation height $(1.6 \pm 1.24 \mathrm{~m})$ (Table II).

The habitat stucture differed significantly between the nine areas: ANOVA, vegetation height $F_{8,216}=13.442, P<0.01$; frequency of clearings 


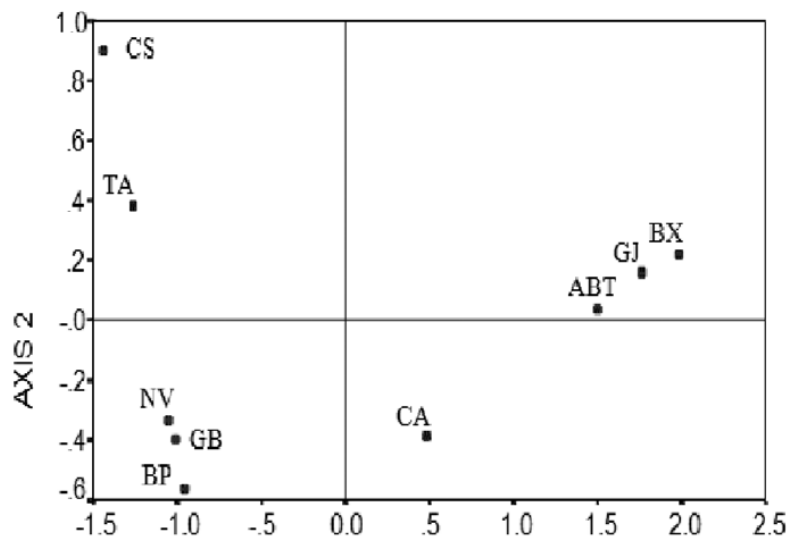

AXIS 1

Fig. 3 - Multidimensional Scaling (MDS) comparing Squamata species composition among the nine restinga ecosystems studied on the coast of the State of Bahia, Brazil: $\mathrm{CA}=$ Costa Azul; $\mathrm{BX}=$ Baixio; $\mathrm{GJ}=$ Guarajuba; $\mathrm{ABT}=$ Abaeté; $\mathrm{GB}=$ Guaibim; $\mathrm{BP}=$ Boipeba $\mathrm{CS}=$ Cassange $\mathrm{TA}=$ Taipe $\mathrm{NV}=$ Nova Viçosa.

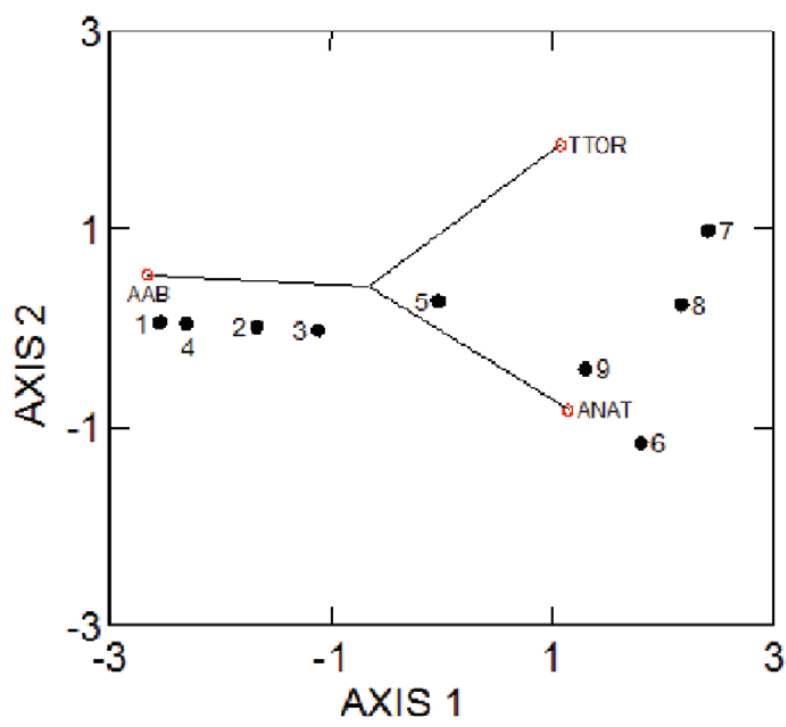

Fig. 4 - Biplot of Squamata species x studied areas of restinga ecosystems on the coast of the State of Bahia, Brazil, using three lizards species, Ameivula abaetensis (AAB), Ameivula nativo (ANAT) and Tropidurus torquatus (TTOR) as correspondence analysis factors: $1=$ Costa Azul; 2 = Baixio; 3 Guarajuba; 4 = Abaeté; $5=$ Guaibim; $6=$ Boipeba; $7=$ Cassange; $8=$ Taipe; $9=$ Nova Viçosa.

$F_{8,216}=6.27, P<0.01$; number of bromeliads $F_{6,170}$ $=3.018, P<0.01$ and number of palm trees $F_{6,170}=$ $6.257, P<0.01$ (Appendices 1-4).

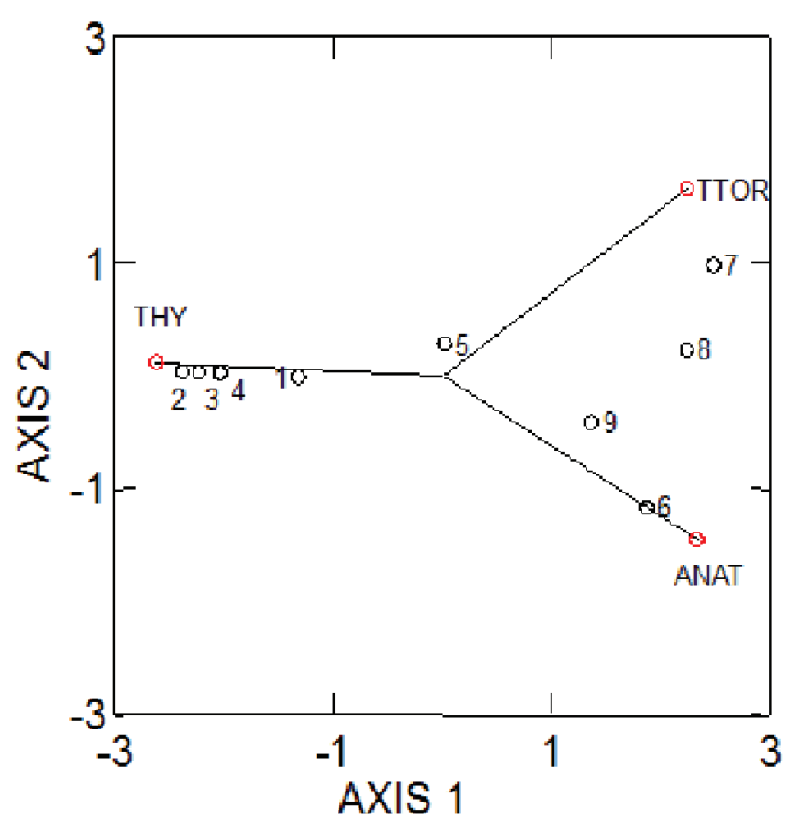

Fig. 5 - Biplot of Squamata species x studied areas of restinga ecosystems on the coast of the State of Bahia, Brazil, using three lizards species Ameivula nativo (ANAT) and Tropidurus torquatus (TTOR) and Tropidurus hygomi (THY) as correspondence analysis fators: 1 = Costa Azul; 2 = Baixio; 3 = Guarajuba; 4 = Abaeté; $5=$ Guaibim; $6=$ Boipeba; $7=$ Cassange; 8 = Taipe; $9=$ Nova Viçosa.

The multidimensional scaling (MDS) showed that the restinga of Boipeba, Taipe and Nova Viçosa (stress $\left.=0.111, R^{2}=0.956\right)$ were comparatively more similar in terms of the complexity of habitat structure, and that the restinga of the Costa Azul was the most different among the other eight studied restinga areas (Fig. 6).

The multiple regression analysis showed that the richness of Squamata species was significantly affected $\left(R^{2}=0.941, N=9, P<0.05\right)$ by parameters of habitat structure of the restinga. However, only frequency of clearings explained an additional portion of the variation in species richness after factoring out the effect of the other variables of heterogeneity analyzed $(P=0.039)$.

Appendices 5 and 6 show the significance levels between abundance of Squamata species and the vegetation height and frequency of clearings in each restinga. These two variables significantly 
TABLE II

Mean, standad deviation (with range within parentheses) of vegetation height, frequency of clearings, bromeliads and palm trees of nine areas of restinga ecosystems studied along the coast of the State of Bahia : $\mathbf{C A}=$ Costa Azul; $B X=$ Baixio; $G J=$ Guarajuba; $A B T=$ Abaeté; $\mathbf{G B}=$ Guaibim; $\mathrm{BP}=$ Boipeba $\mathbf{C S}=$ Cassange $; \mathrm{TA}=$ Taipe $\mathbf{N V}=$ Nova Viçosa.

\begin{tabular}{ccccc}
\hline \multirow{2}{*}{ Study Areas } & \multicolumn{5}{c}{ Environmental Variables } \\
\cline { 2 - 5 } & Vegetation height $(\mathbf{m})$ & Frequency of clearings & Bromeliads & Palm trees \\
\hline CA & $3.7 \pm 2.07(0.3-8.0)$ & $0.09 \pm 0.13(0.0-0.4)$ & $9.7 \pm 10.7(0-35)$ & $4.5 \pm 6.3(0-21)$ \\
BX & $1.6 \pm 1.2(0.2-5.0)$ & $0.56 \pm 0.37(0.0-1.0)$ & $3.1 \pm 6.3(0-40)$ & $0.8 \pm 1.9(0-9)$ \\
GJ & $1.25 \pm 1.5(0.0-6.0)$ & $0.38 \pm 0.45(0.0-1.0)$ & $4.3 \pm 9.3(0-40)$ & $0.6 \pm 1.6(0-7)$ \\
ABT & $1.8 \pm 2.18(0.0-7.0)$ & $0.24 \pm 0.33(0.0-1.0)$ & $1.7 \pm 3.7(0-13)$ & $0.4 \pm 1.4(0-6)$ \\
GB & $5.6 \pm 2.17(0.1-8.0)$ & $0.09 \pm 0.28(0.0-1.0)$ & $0.87 \pm 1.8(0-6)$ & $0.26 \pm 0.61(0-2)$ \\
BP & $3.5 \pm 2.5(0.3-9.0)$ & $0.3 \pm 0.4(0.0-1.0)$ & $2.7 \pm 11.7(0-55)$ & $1.1 \pm 1.7(0-5)$ \\
CS & $5.2 \pm 3.2(0.15-10.0)$ & $0.08 \pm 0.23(0.0-1.0)$ & $0.71 \pm 1.6(0-7)$ & $3.6 \pm 5.5(0-16)$ \\
TA & $4.7 \pm 2.2(0.5-9.0)$ & $0.08 \pm 0.2(0.0-0.69)$ & $2.2 \pm 6.9(0-30)$ & $0.19 \pm 0.69(0-3)$ \\
NV & $4.0 \pm 2.5(0.0-8.0)$ & $0.16 \pm 0.37(0.0-1.0)$ & $2.9 \pm 5.4(0-20)$ & $1.5 \pm 2.2(0-8)$ \\
\hline
\end{tabular}

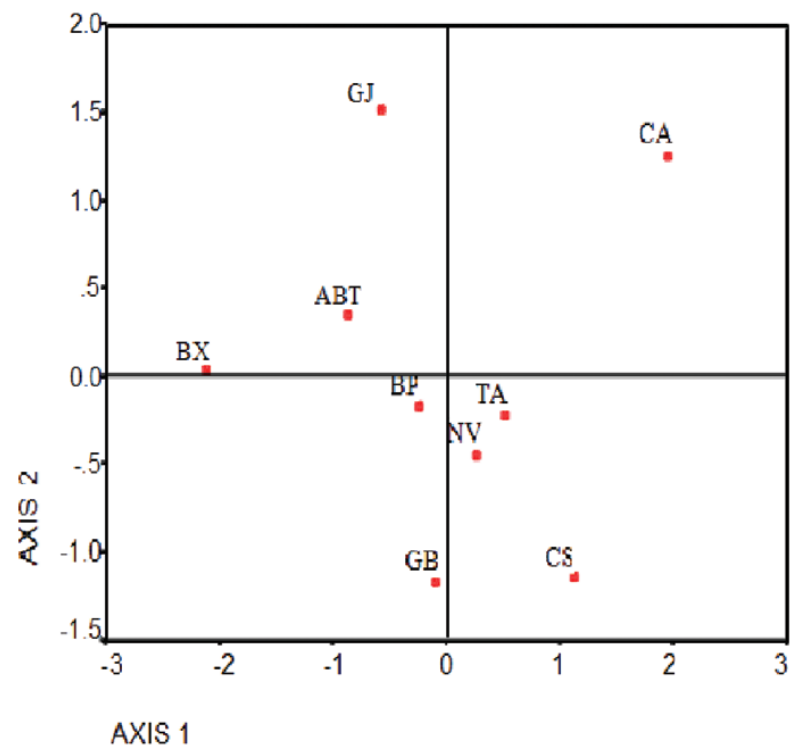

Fig. 6 - Multidimensional Scaling (MDS) comparing the attributes, frequency of occurrence of bromeliads and palm trees, vegetation height and frequency of clearings between the nine restinga ecosystems studied on the coast of the State of Bahia, Brazil: $\mathrm{CA}=$ Costa Azul; $\mathrm{BX}=$ Baixio; $\mathrm{GJ}=$ Guarajuba; $\mathrm{ABT}=$ Abaeté; $\mathrm{GB}=$ Guaibim; $\mathrm{BP}=$ Boipeba; $\mathrm{CS}=$ Cassange; $\mathrm{TA}=$ Taipe; $\mathrm{NV}=$ Nova Viçosa.

affected the distribution of some lizards species such as the lizard Ameivula ocellifera and A. nativo and Tropidurus torquatus, whose abundances were positively affected by the occurrence of areas with high proportion of clearings. The abundance of Tropidurus hygomi was positively and significantly affected by vegetation height and frequency of clearings. Ecpleopus gaudichaudi, the most abundant reptile species in Nova Viçosa, had its abundance positively and significantly affected by vegetation height. In this study, the number of bromeliads and palm trees did not vary significantly among restingas studied and therefore had no significant effect on the abundance of Squamata species.

\section{DISCUSSION}

The restinga areas located in the north and south of the State of Bahia were comparatively different in terms of lizards species, and habitat structure may have been the main cause of this difference. The genera Ameivula and Tropidurus were responsible for major differences in species composition of the Squamata assemblages.

The pooled richness (Gama diversity) of Squamata in restinga ecosystems in the State of Bahia recorded 36 species or, approximately 5\% of reptile species known for Brazil. This is indicative that the restingas of the State of Bahia reserve a considerable portion of Brazilians' biological diversity and emphasizes the importance of conservation of these ecosystems. It was possible to obtain the first records of occurrence of Ecpleopus gaudichaudi (gymnophthalmids) (Dias and Rocha 2013) for 
the State of Bahia, extending the species known distribution from the State of Espírito Santo and first records for Psycosaura agmosticha for restinga ecosystem (Dias and Rocha 2013). This species is a typical species of the semiarid Caatinga domain (Rodrigues 2000).

Populations of snakes and amphisbeaenians species were relatively less abundant when compared to lizard species. For this reason, most of the information obtained in this study was related to lizards' species.

Our data are suggestive that aspects of structure of vegetation (as vegetation height or occurrence of clearings) affected the richness and abundance of lizard species, by supposedly creating different microhabitat opportunities for particular lizard species, since some species are favored by more closed habitats whereas other are favored by more opened portions of habitat (Rocha and Bergallo 1997). Vegetation can affect patterns of local species diversity and abundance in reptile assemblages, and vegetation height is the variable which has been demonstrated as being the most important in affecting the distribution of vertebrates species in restinga ecosystem (e.g. Rocha and Bergallo 1997, Cerqueira and Freitas 1999, Sawchik et al. 2003, Dias and Rocha 2004, 2007). The vertical increase in the height of vegetation tend to increase the diversity of flora and fauna of its surroundings (Pereira et al. 2001, Assis et al. 2004, Rocha et al. 2004).

Our data showed differences in the lizards assemblages in the coast of Bahia according to their species components. The restinga of the north coast (with the exception of Costa Azul) had the lowest species richness when compared to those of the southern portion of the state. These areas also differed in terms of vegetation structure, especially regarding vegetation height and frequency of clearings; two environmental variables which clearly affected the patterns of spatial heterogeneity within the ecosystem.

It has been suggested that there are some distributional limits for most lizard species registered for restinga along the eastern coast of Brazil (Vanzolini
1988). In the limit of approximately $19^{\circ} \mathrm{S}$ there is a break in the distribution of many species, resulting in considerable differences in species composition northwards and southwards of this limit (Vanzolini 1988). The interruption occurrence of many species near this latitude has been attributed to climatic variation, especially temperature zonation (Vanzolini 1988). Heyer (1988) argued the existence of a gradient of rainfall and temperature regimes in the Atlantic Forest Domain from North towards South, whereas Rocha (2000) suggested a region enclosing the northern portion of the State of Espírito Santo and southern portion of the State of Bahia as limits of different coastal climatic regimes that could affect several reptile species, resulting in differences in the local component of reptile assemblage. Another factor out as being important with regards to influencing reptile fauna distribution in the Atlantic Forest is the presence of the large Doce river, which seems to also influence southern and northern geographic limits of the distribution for many species (Rocha 2000). According to a theory (Jakson 1978), this region was considered a Pleistocene refuge area between the north of the State of Espírito Santo and the south of the State of Bahia which currently coincides with several breaks in the distribution of some lizard species (e.g. genus Enyalius and Strobilurus) leading to geographical differences in species distribution.

Our study showed that three lizard species of the genus Ameivula were found along the coast of the State of Bahia. However, some segregation in distribution among these species were noticed: Ameivula abaetensis and A. ocellifera had a distribution restricted to the northern coast and $A$. nativo to the southern coast. Similarly, the genus Tropidurus had two species distributed in the same area, with $T$. hygomi occurring only in the northern portion of coastal restingas while $T$. torquatus occurred in the southern portion of the coast. Amongst these five species Ameivula abaetensis, A. nativo and Tropidurus hygomi are known to occur only in restinga and thus, are endemic to this ecosystem. 
On the other hand T. torquatus and A. ocellifera occur widely in other Brazilian ecosystems such as the Atlantic Forest (sensu stricto), the Cerrado, the Caatinga and rocky fields (Vanzolini et al. 1980, Vitt 1991, 1995, Vitt and Carvalho 1995).

These lizards of the genera Ameivula and Tropidurus occur in simpatry in restinga ecosystem with other lizards such as Ameiva Ameiva, Psycosaura macrorhyncha and Brasiliscincus agilis with a general trend of lizards of genera Ameivula and Tropidurus being usually more abundant when compared to the former species. In part, this seems to result from the fact that Ameivula and Tropidurus lizards have their occurrences mainly associated to open habitats which is the condition predominant in restinga ecosystem (Rocha and Bergallo 1997, Rocha 2000), whereas sympatric lizards in the other genera prefer more shaded environments in restinga (Vrcibradic and Rocha 1996, Rocha and Bergallo 1997, Zaluar and Rocha 2000). In fact the species A. Ameiva, P.macrorhyncha and B. agilis were more abundant in southern restinga of the State of Bahia and may probably result from the fact of these restinga areas being dominated by comparatively taller vegetation with lower frequency of clearings.

The occurrence of some lizard species in specific microhabitats has been shown to be directly related to the type use of preferred substrate (Barbault and Maury 1981, Shenbrot et al. 1991). However, the natural condition of substrate interacts with other factors such as vegetation height, presence of open and closed habitats and seasonal environmental conditions, affecting the distribution of the organisms in the local assemblage (Rocha 1991, Kikuchi and Uieda 2005). Among the restinga ecosystems in the State of Bahia, those in the north portion had comparatively higher frequency of extensions of bare sand and open areas, which potentially favored the occurrence of some lizards species that prefer more opened habitats such as the T. hygomi, Ameivula ocellifera and A. abaetensis. Conversely, in these more opened areas some species such as Ameiva ameiva, Kentropyx calcarata and Gymnodactylus darwinii were less frequent, presumably as a result of the lower availability of shaded habitats.

The restinga ecosystems from the southern portion differed from those of the northern portion of the State of Bahia by having comparatively more extensions with shaded areas, taller vegetation (approximately $5 \mathrm{~m}$ ) and consequently, more extensions of soil surface covered by leaf litter. In these areas lizard assemblages tended to be composed by lizards species that preferentially use these types of habitat structure and therefore, in general, differed in the richness, composition and frequency from those restinga of the northern portion of the State of Bahia. The vegetation structure was an important factor for determining Squamata assemblage along the coast of the State of Bahia, and some lizards species were particularly indicative of the local habitat structural complexity.

The variation in species composition of Squamata in restinga ecosystems in the State of Bahia may also have been affected by historical factors of regional formation. However, we believe that environmental factors have great importance in the distribution patterns of species observed. The merit of this study lies in trying to estimate and especially emphasize environmental factors that may be important in the establishments of relevant patterns of species distribution.

\section{ACKNOWLEDGMENTS}

This study is a portion of the results of the "Programa de Ecologia, Conservação e Manejo de Ecossistemas do Sudeste Brasileiro" and of the Southeastern Brazilian Vertebrate Ecology Project (Vertebrate Ecology Laboratory), both of the Departamento de Ecologia, Instituto de Biologia, Universidade do Estado do Rio de Janeiro. We thank Igor Rios do Rosário for drawing the map and two anonymous reviewers for several suggestions. The Ministério do Meio Ambiente conceded permits for the collection of lizards for our study. The Fundação Carlos Chagas Filho de Amparo à Pesquisa do Estado do Rio de 
Janeiro (FAPERJ) provided a Graduate fellowship to the first author (Process no. E-26/150.898/2001) and CFD Rocha received research grants from the Conselho Nacional de Desenvolvimento Científico e Tecnológico (CNPq) (processes 304791/2010-5 and 470265/2010-8) and from the Fundação Carlos Chagas Filho de Amparo à Pesquisa do Estado do Rio de Janeiro (FAPERJ) through "Cientistas do Nosso Estado" Program (process E-26/102.404.2009). We also thank the Critical Ecosystem Partnership Fund (CEPF) and IDEAWILD for research grants for the development of this study.

\section{RESUMO}

Neste trabalho, pesquisamos os dados de riqueza e composição de répteis Squamata e o efeito estrutural do habitat em nove áreas do ecossistema de restinga no Estado da Bahia, nordeste do Brasil. Os ecossistemas de "restinga" são habitats costeiros de dunas de areia na costa do Brasil. Nossa hipótese principal é que a composição da fauna de Squamata ao longo das áreas de restinga seria modulada pela estrutura do habitat. Após 90 dias de pesquisa em campo registramos aproximadamente $5 \%$ das espécies de répteis conhecidas no Brasil. A composição das assembleias de Squamata variou principalmente com base na presença ou ausência dos gêneros de lagartos Ameivula e Tropidurus. Nossos dados mostraram que a estrutura do habitat afetou significativamente a composição da fauna local de Squamata, especialmente os lagartos.

Palavras-chave: Análise de gradiente, estrutura do habitat, lagartos e serpentes, ecossistema de restinga, vegetação, Nordeste do Brasil.

\section{REFERENCES}

Assis AM, PEREIRA OJ AND ThOMAZ LD. 2004. Fitossociologia de uma floresta de restinga no Parque estadual Paulo César Vinha, Setiba, município de Guaraparí (ES). Rev Bras Bot 27: 349-361.

Araujo DSD, PEREIRA MCA AND PIMENTEl MCP. 2004. Flora e estrutura de comunidades na restinga de Jurubatiba Síntese dos conhecimentos com enfoque especial para a formação aberta de Clusia. In: ROCHA CFD, ESTEVES FA AND SACARANO FB (Eds), Pesquisas de longa duração na restinga de Jurubatiba: Ecologia, história natural e conservação, São Carlos: Rima Editora, p. 59-76.
Araujo DSD, ScARano FR, SÁ CFC, KuRTZ BC, ZALUar HTL, Montezuma RCM AND OliveIRA RC. 1998. Comunidades vegetais do Parque Nacional da Restinga de Jurubatiba. In: ESTEVES FA (Ed), Ecologia das lagoas costeiras do Parque Nacional das Restingas de Jurubatiba e do Município de Macaé (RJ), Rio de Janeiro: Universidade Federal do Rio de Janeiro, p. 39-62.

BARBAUlT R AND MAURY ME. 1981. Ecological organization of a Chihuahuan desert lizards community. Oecologia 51: $335-342$

CERqueira R AND Freitas SR. 1999. A new method of microhabitat structure of small mammals. Rev Bras Biol 59: 219-223.

Cogliatti-CARVAlHo L, Freitas AFN, Rocha CFD AND VAN SLUYS M. 2001. Variação na estrutura e na composição de Bromeliaceae em cinco zonas de restinga no Parque Nacional da Restinga de Jurubatiba, Macaé, RJ. Rev Bras Bot 24: 1-9.

Cogliatti-Carvalho L, Rocha-Pessoa TC, Freitas AFN AND RocHA CFD. 2010. Volume de água armazenado no tanque de bromélias, em restingas da costa brasileira. Acta Bot Bras 24: 84-95.

DANSEREAU P. 1947. Zonation et sucession sur la restinga de Rio de Janeiro. Rev Can Biol 6: 448-477.

DiAS EJR AND RochA CFD. 2004. Thermal ecology, activity pattern and microhabitat use by two sympatric whiptail lizards (Cnemidophurus abaetensis and C. ocellifer) from Northeastern Brazil. J Herpetol 38: 595-588.

DIAS EJR AND RochA CFD. 2013. Ecpleopus gaudichaudi Duméril and Bibron, 1839 (Squamata: Gymnophthalmidae) and Psychosaura agmosticha (Rodrigues, 2000) (Squamata: Scincidae): Distribution extension and new records from Atlantic Forest in Bahia state, Brazil. Check List 9(3): 607-609.

FRANCO AC, VALERIANO DM, SANTOS FM, HAY JD, HENRIQUES RPB AND MEDEIROS RA. 1984. Os microclimas das zonas de vegetação da praia da restinga de Barra de Marica, Rio de Janeiro. In: LACERDA LD, ARAUJO DSD, CERQUEIRA R AND TURCQ B (Eds), Restinga: Origens, estrutura e processos. Niterói: Universidade Federal Fluminense, p. 413-423.

Gotelli NJ AND ENTSMINGER GL. 2001. EcoSim: Null models software for ecology. Version 7.0. Acquired Intelligence Inc. \& Kesey-Bear. [S. 1.: s. n.] $<$ http://homepages.together. net/ gentsmin/ecosim.htm> Acessed in 10 March 2013.

HAFFER J. 1969. Speciation in Amazonian forest birds. Science. 165:131-137.

HENRIQUES RPB, ARAUJO DSD AND HAY JD. 1986. Descrição e classificação dos tipos de vegetação da restinga de Carapebus, Rio de Janeiro. Rev Bras Bot 9: 173-189.

HeYer WR. 1988. Frog Distribution Patterns in East of the Andes. In: VANZOLINI PE AND HEYER WR (Eds), Proceedings of Workshop on Neotropical Distribution Patterns. Rio de Janeiro: Academia Brasileira de Ciências, p. 245-273.

JAKSON JF. 1978. Differentiation in the genera Enyalius and Strobilurus (Iguanidae): Implications for Pleistocene climatic changes in eastern Brazil. Arq Zoologia 30: 1-79. 
KENKEL NC AND ORLÓCI L. 1986. Applying metric and nonmetric multidimentional scaling to ecological studies: some new results. Ecology 67: 919-928.

KIKUCHI RM AND UIEDA VS. 2005. Composição e distribuição dos macroinvertebrados em diferentes substratos de fundo de um riacho no município de Itatinga, São Paulo, Brasil. Entomol Vect 12: 193-231.

KREBS CJ. 1989. Ecological Methodology. New York: Harper and Raw Publishers, $654 \mathrm{p}$.

LACERDA LD, ARAUJO DSD AND MACIEL NC. 1993. Dry costal ecossystems of the tropical brazilian cost. In: VAN DER MAAREL E (Ed), Dry coatal-ecossystems: Africa, Asia, Oceania. Amsterdam: Elsevier, p. 477-493.

Losos J. 1994. Historical contigency and lizard community ecology. In: VITT LJ AND PIANKA ER. Lizard Ecology: Historical and Experimental Perspectives. Princenton: Princeton University Press, p. 319-333.

MINCHIN PR. 1997. Evaluation of the relative robustness of techniques for ecological ordination. Vegetation 69: 89-107.

ORMOND WT. 1960. Ecologia das restingas do Sudeste do Brasil: Comunidades vegetais das praias arenosas. Arq Mus Nac 50: 185-236.

Pereira MCA, ARAuJo DSD AND PEREIRA OJ. 2001. Estrutura de uma comunidade arbustiva da restinga de Barra de Marica, Rio de Janeiro. Rev Bras Bot 24: 273-281.

Pereira OJ, Thomaz LD AND Araujo DSD. 1992. Fitossociologia da vegetação de ante dunas da restinga de Setiba/Guarapari e em Interlagos/Vila Velha, ES. Bol Mus Biol Mello Leitão (N. Sér) 1: 65-78.

PIANKA ER. 1973. The struture of lizards communities. Annu Rev Ecol Syst 4: 53-74.

PIANKAER. 1986. Ecology and natural history of desert lizards. Princenton: Princeton University Press, 208 p.

RochA CF. 1991. Composição do hábitat e uso do espaço por Liolaemus lutzae (Sauria: Tropiduridae) em uma área de restinga. Rev Bras Biol 51: 671-678.

Rocha CF. 2000. Biogeografia de Répteis de Restinga: Distribuição, Ocorrência e Endemismos. In: ESTEVES FA AND LACERDA LD. Ecologia de Restingas e Lagoas Costeiras. Macaé: Universidade Federal do Rio de Janeiro, p. 99-116.

Rocha CFD AND Bergallo HG. 1997. Intercommunity Variation in the Distribution of Abundance Lizards Species in Restinga Habitats. Cienc Cult 4: 269-274.

Rocha CFD, Cogliatti-CARVAlHo L, Nunes-Freitas AF, Rocha-Pessôa TC, Dias AS, ARIANE CV and Morgado LN. 2004. Conservado uma larga porção da diversidade biológica através da conservação de Bromeliácea. Vidália 2: $52-72$.
RODRIGUES MT. 2000. A new species of Mabuya (Squamata: Scincidae) from the semiarid Caatingas of northeastern Brazil. Pap Avulsos de Zool (São Paulo) 41: 313-328.

SAWCHIK J, DUFRÊNE M AND LEBRUN P. 2003. Estimation of habitat quality based on plant community and effects of isolation in a net work of butterfly habitat patches. Acta Oecol 24: 22-33.

SCARANO FR. 2002. Structure, function and floristic relationship of plant communities in stressful habitats marginal to the Brazilian Atlantic rainforest. Ann Bot 90: 517-524.

SCHOENER TW. 1968. The Anolis lizards of Bimini: resource partitioning ina complex fauna. Ecology 49: 704-726.

Schoener TW. 1974. Resource Partitioning in Ecological Communities. Science 185: 27-39.

SHenBrot GI, REGOVIn KA AND Surov AV. 1991. Comparative Analysis of Spatial Organization of Desert Lizard Communities in Middle Asia and Mexico. Oikos 61: 157-168.

STONE L AND RoBERTS A. 1990. The checkerboard score and species distribution. Oecologia 85: 74-79.

VANZOLINI PE. 1988. Distributional Patterns of South American Lizards. In: VANZOLINI PE AND HEYER WR (Eds), Proceedings of Workshop on Neotropical Distribution Patterns. Rio de Janeiro: Academia Brasileira de Ciências, p. 317-342.

VANZOLINI PE, RAMOS-COSTA AM AND VitT LJ. 1980. Répteis das caatingas. Rio de Janeiro: Academia Brasileira de Ciência, $161 \mathrm{p}$.

VITT LJ. 1991. An Introduction to the Ecology of Cerrado Lizards. J Herpetol 1: 79-90.

VITT LJ. 1995. The ecology of tropical lizards in the caatinga of Northeast Brazil. Occ Pap Okla Mus Nat Hist 1: 1-29.

VitT LJ AND CARVAlHo CM. 1995. Niche Partitioning in a Tropical Wet Season: Lizard in the Lavrado Area of Northern Brazil. Copeia 2: 305-329.

VITT LJ, ZANI PA AND EsPÓSITO MC. 1999. Historical Ecology of Amazonian Lizards: Implications for Community Ecology. Oikos 87: 286-294.

VRCIBRADIC D AND ROCHA CFD. 1996. Ecological Differences in Tropical Sympatric Skinks (Mabuya macrorhyncha and Mabuya agilis) in the Southeaestern Brazil. J Herpetol 1: 60-67.

ZALUAR HLT AND ROCHA CFD. 2000. Ecology of the wideforaging lizard Ameiva ameiva (Teiidae) in a sand dune habitat of Southeast Brazil: Ontogenetic, sexual and seasonal trends in food habitats, activity, thermal biology and microhabitat use. Cienc Cult 1: 101-107.

ZAR JH. 1999. Biostatistical Analiysis. New Jersey: PrenticeHall, $718 \mathrm{p}$. 


\section{APPENDICES}

\section{Appendix 1}

Values of the significant probability of Bonferroni test for vegetation height in analysis of variance (ANOVA) for differences between pairs of restingas: $\mathbf{C A}=\mathbf{C o s t a} \mathrm{Azul}$; $\mathbf{B X}=\mathbf{B a i x i o}$; $\mathbf{G J}=\mathbf{G u a r a j u b a}$; ABT $=$ Abaeté $; \mathbf{G B}=$ Guaibim $; \mathrm{BP}=$ Boipeba $\mathbf{C S}=$ Cassange $; \mathrm{TA}=$ Taipe $\mathbf{N V}=$ Nova Viçosa.

\begin{tabular}{|c|c|c|c|c|c|c|c|c|c|}
\hline \multirow{2}{*}{ Study Areas } & \multicolumn{9}{|c|}{ Study Areas } \\
\hline & $\mathrm{CA}$ & $\mathrm{BX}$ & GJ & $\mathrm{ABT}$ & GB & BP & $\mathrm{CS}$ & TA & NV \\
\hline \multicolumn{10}{|l|}{$\mathrm{BX}$} \\
\hline GJ & 0.007 & & & & & & & & \\
\hline \multicolumn{10}{|l|}{$\mathrm{ABT}$} \\
\hline GB & & $<0.001$ & $<0.001$ & $<0.001$ & & & & & \\
\hline BP & & & 0.011 & & & & & & \\
\hline $\mathrm{CS}$ & & $<0.001$ & $<0.001$ & $<0.001$ & & & & & \\
\hline TA & & $<0.001$ & $<0.001$ & $<0.001$ & & & & & \\
\hline NV & & $<0.001$ & $<0.001$ & 0.009 & & & & & \\
\hline
\end{tabular}

Appendix 2

Values of the significant probability of Bonferroni test for frequency of clearings in analysis of variance (ANOVA) for differences between pairs of restingas: $\mathbf{C A}=$ Costa $\mathbf{A z u l}$; $\mathbf{B X}=$ Baixio; $\mathbf{G J}=$ Guarajuba; ABT $=$ Abaeté; $\mathbf{G B}=$ Guaibim; $\mathrm{BP}=$ Boipeba $\mathbf{C S}=$ Cassange; $\mathrm{TA}=$ Taipe $\mathbf{N V}=$ Nova Viçosa.

\begin{tabular}{|c|c|c|c|c|c|c|c|c|c|}
\hline \multirow{2}{*}{ Study Areas } & \multicolumn{9}{|c|}{ Study Areas } \\
\hline & $\mathrm{CA}$ & $\mathrm{BX}$ & GJ & $\mathrm{ABT}$ & GB & $\mathrm{BP}$ & $\mathrm{CS}$ & TR & $\mathrm{NV}$ \\
\hline $\mathrm{BX}$ & $<0.001$ & & & & & & & & \\
\hline GJ & & & & & & & & & \\
\hline $\mathrm{ABT}$ & & 0.025 & & & & & & & \\
\hline GB & & $<0.001$ & & & & & & & \\
\hline $\mathrm{BP}$ & & & & & & & & & \\
\hline $\mathrm{CS}$ & & $<0.001$ & & & & & & & \\
\hline TA & & $<0.001$ & $<0.001$ & & & & & & \\
\hline NV & & $<0.001$ & & & & & & & \\
\hline
\end{tabular}

Appendix 3

Values of the significant probability of Bonferroni test for number of bromeliads in analysis of variance (ANOVA) for differences between pairs of restingas: $\mathbf{C A}=\mathbf{C o s t a} \mathrm{Azul}$; $\mathbf{B X}=\mathbf{B a i x i o}$; $\mathbf{G J}=\mathbf{G u a r a j u b a}$; ABT $=$ Abaeté; $\mathbf{G B}=$ Guaibim; $\mathrm{BP}=$ Boipeba $\mathbf{C S}=$ Cassange; $\mathrm{TA}=$ Taipe $\mathbf{N V}=$ Nova Viçosa.

\begin{tabular}{|c|c|c|c|c|c|c|c|c|c|}
\hline \multirow{2}{*}{ Study Areas } & \multicolumn{9}{|c|}{ Study Areas } \\
\hline & $\mathrm{CA}$ & $\mathrm{BX}$ & GJ & $\mathrm{ABT}$ & GB & $\mathrm{BP}$ & $\mathrm{CS}$ & TR & NV \\
\hline \multicolumn{10}{|l|}{$\mathrm{BX}$} \\
\hline \multicolumn{10}{|l|}{ GJ } \\
\hline ABT & $<0.001$ & & & & & & & & \\
\hline GB & $<0.001$ & & & & & & & & \\
\hline \multicolumn{10}{|l|}{$\mathrm{BP}$} \\
\hline \multicolumn{10}{|l|}{$\mathrm{CS}$} \\
\hline TA & $<0.001$ & & & & & & & & \\
\hline NV & $<0.001$ & & & & & & & & \\
\hline
\end{tabular}




\section{Appendix 4}

Values of the significant probability of Bonferroni test for number of palm trees in analysis of variance (ANOVA) for differences between pairs of restingas: $\mathbf{C A}=$ Costa Azul; $\mathbf{B X}=$ Baixio; $\mathbf{G J}=\mathbf{G u a r a j u b a}$; $\mathrm{ABT}=$ Abaeté $\mathbf{G B}=$ Guaibim $; \mathrm{BP}=$ Boipeba $\mathrm{CS}=$ Cassange $\mathbf{T A}=$ Taipe $\mathbf{N V}=$ Nova Viçosa.

\begin{tabular}{|c|c|c|c|c|c|c|c|c|c|}
\hline \multirow{2}{*}{ Study Areas } & \multicolumn{9}{|c|}{ Study Areas } \\
\hline & $\mathrm{CA}$ & $\mathrm{BX}$ & GJ & $\mathrm{ABT}$ & GB & $\mathrm{BP}$ & $\mathrm{CS}$ & TR & NV \\
\hline \multicolumn{10}{|l|}{$\mathrm{BX}$} \\
\hline GJ & $<0.001$ & & & & & & & & \\
\hline \multicolumn{10}{|l|}{$\mathrm{ABT}$} \\
\hline GB & $<0.001$ & & & & & & & & \\
\hline $\mathrm{BP}$ & $<0.001$ & & & & & & & & \\
\hline $\mathrm{CS}$ & & & 0.018 & & 0.011 & & & & \\
\hline TR & $<0.001$ & & & & & & & & \\
\hline NV & $<0.001$ & & & & & & & & \\
\hline
\end{tabular}

\section{Appendix 5}

Values of the significant probability of the Regression analysis between vegetation heigh and abundance of Squamata species in restinga ecosystems: $\mathbf{C A}=\mathbf{C o s t a} \mathrm{Azul}$; $\mathbf{B X}=$ Baixio; GJ= Guarajuba; $\mathbf{A B T}=\mathbf{A b a e t e ́ ;}$ $\mathbf{G B}=$ Guaibim $; \mathrm{BP}=$ Boipeba $\mathbf{C S}=$ Cassange; $\mathrm{TA}=$ Taipe $\mathbf{N V}=$ Nova Viçosa.

\begin{tabular}{|c|c|c|c|c|c|c|c|c|c|}
\hline \multirow{2}{*}{ LIZARDS SPECIES } & \multicolumn{9}{|c|}{ STUDY AREAS } \\
\hline & $\mathrm{CA}$ & $\mathrm{BX}$ & GJ & ABT & GB & $\mathrm{BP}$ & $\mathrm{CS}$ & TA & NV \\
\hline Ameivula abaetensis & & & & 0.03 & & & & & \\
\hline \multicolumn{10}{|l|}{ Ameivula ocellifera } \\
\hline \multicolumn{10}{|l|}{ Ameivula nativo } \\
\hline Tropidurus hygomi & 0.009 & & & 0.002 & & & & & \\
\hline Tropidurus torquatus & & & & & & & & 0.01 & \\
\hline \multicolumn{10}{|l|}{ Psycosaura macrorhyncha } \\
\hline Gymnodactylus darwinii & & & & & & & & & 0.004 \\
\hline Hemidactylus mabouia & & & & & & & & & 0.001 \\
\hline Ecpleopus gaudichaudii & & & & & & & & & 0.05 \\
\hline
\end{tabular}

\section{Appendix 6}

Values of the significant probability of the Regression analysis between frequency of clearing and abundance of Squamata species in nine restinga ecosystems studied in coastal Bahia state, Brazil: $\mathbf{C A}=$ Costa Azul; BX= Baixio; GJ= Guarajuba; ABT= Abaeté; $\mathbf{G B}=$ Guaibim; $\mathbf{B P}=$ Boipeba; $\mathbf{C S}=$ Cassange; $\mathbf{T A}=$ Taipe; NV= Nova Viçosa.

\begin{tabular}{|c|c|c|c|c|c|c|c|c|c|}
\hline \multirow{2}{*}{ LIZARDS SPECIES } & \multicolumn{9}{|c|}{ RESTINGAS } \\
\hline & $\mathrm{CA}$ & $\mathrm{BX}$ & GJ & $\mathrm{ABT}$ & GB & $\mathrm{BP}$ & $\mathrm{CS}$ & TA & NV \\
\hline \multicolumn{10}{|l|}{ Ameivula abaetensis } \\
\hline Ameivula ocellifera & 0.02 & 0.002 & & & & & & & \\
\hline Ameivula nativo & & & & & & 0.003 & $<0.001$ & 0.01 & \\
\hline Tropidurus hygomi & & $<0.001$ & 0.002 & & & & & & \\
\hline Tropidurus torquatus & & & & & $<0.001$ & & $<0.001$ & 0.001 & \\
\hline Psycosaura macrorhyncha & & & & & & & 0.025 & & \\
\hline \multicolumn{10}{|l|}{ Gymnodactylus darwinii } \\
\hline \multicolumn{10}{|l|}{ Hemidactylus mabouia } \\
\hline Ecpleopus gaudichaudii & & & & & & & & & \\
\hline
\end{tabular}

